\title{
Using Molecular Iodine in Direct Oxidative Condensation of Aldoses with Diamines: An Improved Synthesis of Aldo-benzimidazoles and Aldo-naphthimidazoles for Carbohydrate Analysis
}

\author{
Chunchi Lin, ${ }^{\dagger}$ Po-Ting Lai, ${ }^{\ddagger}$ Sylvain Kuo-Shiang Liao, ${ }^{\dagger}$ Wei-Ting Hung, ${ }^{\dagger}$ \\ Wen-Bin Yang, ${ }^{* \dagger}$ and Jim-Min Fang ${ }^{*}, *$ \\ The Genomics Research Center, Academia Sinica, Taipei, 11529, Taiwan, and Department of Chemistry, \\ National Taiwan University, Taipei 106, Taiwan \\ wbyang@gate.sinica.edu.tw; jmfang@ntu.edu.tw
}

Received January 29, 2008

\section{Introduction}

In nature, 5,6-dimethyl-1-( $\alpha$-D-ribofuranosyl)benzimidazole exists as a moiety of vitamin $\mathrm{B}_{12}{ }^{1}{ }^{1}$ The furanosyl benzimidazole can be considered as a $C$-nucleoside mimic. ${ }^{1}$ Due to its structural similarity to purine, benzimidazole is also an important chemical entity in pharmaceuticals. ${ }^{2}$ In one approach, aldo-benzimidazoles are prepared by condensation of aldonic acids or aldonic $\delta$-lactones with $o$-phenylenediamines (Scheme 1). ${ }^{3}$ The condensation reactions are often conducted in strong acidic conditions at elevated temperature (e.g., $\left.135^{\circ} \mathrm{C}\right){ }^{3 a}$ The tetritol-1-yl

\footnotetext{
${ }^{\dagger}$ The Genomics Research Center.

* National Taiwan University.

(1) Townsend, L. B.; Revankar, G. R. Chem. Rev. 1970, 70, 389-438.

(2) Freeman, G. A.; Selleseth, D. W.; Rideout, J. L.; Harvey, R. J. Nucleosides Nucleotides Nucleic Acids 2000, 19, 155-174.

(3) (a) Moore, S.; Link, K. P. J. Biol. Chem. 1940, 133, 293-311. (b) El Ashry, E. S. H.; Awad, L. F.; Hamid, H. A.; Atta, A. I. J. Carbohydr. Chem. 2007, 26, 329-338.

(4) Sallam, M. A. E.; Ibrahim, E. I.; El-Eter, K. A. A.; Cassady, J. M. Carbohydr. Res. 1997, 298, 93-104.

(5) Moore, S.; Link, K. P. J. Org. Chem. 1940, 5, 637-644.

(6) (a) Wistler, R. L., Wolfrom, M. L., Eds. In Methods in Carbohydrates Chemistry., Academic Press: New York, 1963; Vol. 2, pp 13-14. (b) Zhang, T. H.; Marchant, R. E. Macromolecules 1994, 27, 7302-7308. (c) Auzély-Velty, R.; Cristea, M.; Rinaudo, M. Biomacromolecules 2002, 3, 998-1005. (d) Yang, B. Y.; Montgomery, R. Carbohydr. Res. 2005, 340, 2698-2705.
}

SCHEME 1. Previous Synthetic Routes to Saccharide Benzimidazoles

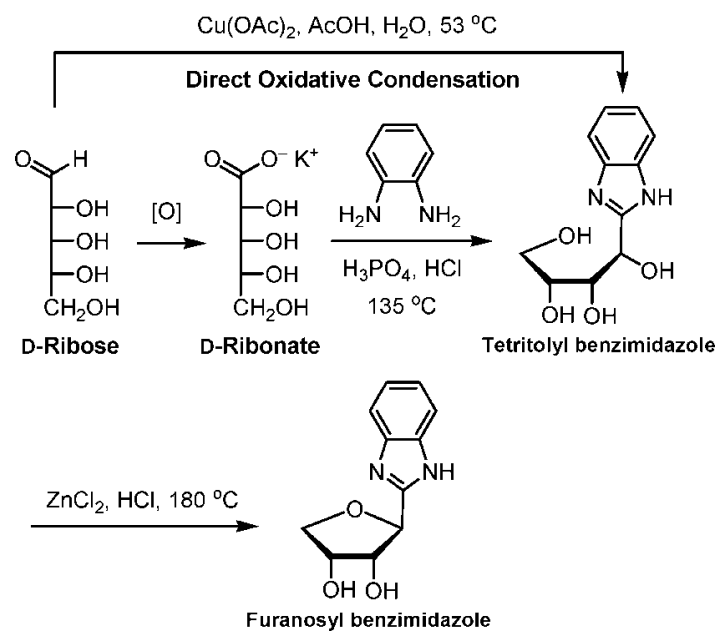

benzimidazoles can be further converted to furanosyl benzimidazoles by a Lewis acid promoted dehydrative cyclization. ${ }^{4}$

In another approach, aldoses are subjected to oxidative condensation with $o$-phenylenediamine to give aldo-benzimidazoles in a direct manner. ${ }^{5}$ This approach mitigates the 
TABLE 1. Oxidative Condensation of Aldoses with $o$-Phenylenediamines or 2,3-Naphthalenediamine ${ }^{a}$

\begin{tabular}{|c|c|c|c|c|c|c|}
\hline entry & sugar & diamine $^{a}$ (equiv) & iodine (equiv) & solvent & imidazole $(\text { yield, } \%)^{b}$ & peracetate (yield, $\%)^{c}$ \\
\hline 1 & D-glucose, 1a & $\mathrm{C}_{6} \mathrm{H}_{4}\left(\mathrm{NH}_{2}\right)_{2}, \mathbf{2 a}(1.1)$ & 0.1 & $\mathrm{AcOH}$ & 3a (98) & \\
\hline 2 & $1 \mathrm{a}$ & $\mathrm{Me}_{2} \mathrm{C}_{6} \mathrm{H}_{2}\left(\mathrm{NH}_{2}\right)_{2}, \mathbf{2 b}(3)$ & 1.0 & aq. $\mathrm{AcOH}$ & & 3b-Ac (58) \\
\hline 3 & 1a & $\mathrm{Cl}_{2} \mathrm{C}_{6} \mathrm{H}_{2}\left(\mathrm{NH}_{2}\right)_{2}, \mathbf{2 c}(2)$ & 0.1 & $\mathrm{AcOH}$ & 3c $(98)$ & \\
\hline 5 & 1a & $\mathrm{O}_{2} \mathrm{NC}_{6} \mathrm{H}_{3}\left(\mathrm{NH}_{2}\right)_{2}, \mathbf{2 e}(2)$ & 0.1 & $\mathrm{AcOH}$ & $3 \mathbf{e}(76)^{d}$ & \\
\hline 6 & $1 \mathbf{a}$ & $\mathrm{PhCOC}_{6} \mathrm{H}_{3}\left(\mathrm{NH}_{2}\right)_{2}, \mathbf{2 f}(2)$ & 0.1 & $\mathrm{AcOH}$ & 3f $(74)^{d}$ & \\
\hline 7 & 1a & $\mathrm{C}_{10} \mathrm{H}_{6}\left(\mathrm{NH}_{2}\right)_{2}, 2 \mathrm{~g}(1.1)$ & 0.1 & $\mathrm{AcOH}$ & $3 \mathbf{g}(98)$ & \\
\hline 8 & 1a & $\mathbf{2 g}(1.1)$ & 0 & $\mathrm{AcOH}$ & $3 \mathbf{g}(33)$ & \\
\hline 11 & 1b & $2 \mathbf{b}(3)$ & 1.0 & aq $\mathrm{AcOH}$ & & 4b-Ac $(80)$ \\
\hline 12 & $1 \mathrm{~b}$ & $2 \mathrm{~g}(1.1)$ & 0.1 & $\mathrm{AcOH}$ & $4 \mathbf{g}(85)$ & \\
\hline 13 & D-mannose, $\mathbf{1 c}$ & $\mathbf{2 a}(3)$ & 1.0 & $\mathrm{aq} \mathrm{AcOH}$ & & 5a-Ac (42) \\
\hline 14 & 1c & $\mathbf{2 b}(3)$ & 1.0 & aq $\mathrm{AcOH}$ & & 5b-Ac (74) \\
\hline 15 & 1c & $2 \mathrm{~g}(1.1)$ & 0.1 & $\mathrm{AcOH}$ & $5 g(96)$ & \\
\hline 16 & D-arabinose, 1d & $\mathbf{2 a}(3)$ & 1.0 & aq $\mathrm{AcOH}$ & & 6a-Ac (60) \\
\hline 22 & 1e & $2 \mathbf{b}(3)$ & 1.0 & aq $\mathrm{AcOH}$ & & 7b-Ac (87) \\
\hline 23 & 1e & $2 \mathrm{~g}(1.1)$ & 0.1 & $\mathrm{AcOH}$ & $7 \mathbf{g}(98)$ & \\
\hline 24 & D-ribose, $\mathbf{1 f}$ & $2 \mathrm{~g}(1.1)$ & 0.1 & $\mathrm{AcOH}$ & $8 g(97)$ & \\
\hline 25 & L-fucose, $1 \mathrm{~g}$ & $2 \mathrm{~g}(1.1)$ & 0.1 & $\mathrm{AcOH}$ & $\mathbf{9 g}(99)$ & \\
\hline 26 & L-rhamnose, 1 h & $2 \mathrm{~g}(1.1)$ & 0.1 & $\mathrm{AcOH}$ & $\mathbf{1 0 g}(99)$ & \\
\hline 27 & D-GlcNAc, $\mathbf{1 i}$ & $2 \mathrm{~g}(1.1)$ & 0.1 & $\mathrm{AcOH}$ & $11 g(94)$ & \\
\hline 28 & D-GlcA, $\mathbf{1 j}$ & $2 \mathrm{~g}(1.1)$ & 0.1 & $\mathrm{AcOH}$ & $12 \mathrm{~g}(97)$ & \\
\hline 29 & D-maltose, $\mathbf{1 k}$ & $\mathbf{2 a}(2)$ & 1.2 & buffer $^{e}$ & & 13a-Ac (78) \\
\hline 30 & $1 \mathrm{k}$ & $\mathbf{2 b}(3)$ & 1.0 & aq $\mathrm{AcOH}$ & & 13b-Ac (66) \\
\hline 31 & $1 \mathrm{k}$ & $2 \mathrm{~g}(1.1)$ & 0.1 & $\mathrm{AcOH}$ & 13g (99) & \\
\hline 32 & D-lactose, $\mathbf{1 l}$ & $\mathbf{2 a}(2)$ & 1.2 & buffer $^{e}$ & & 14a-Ac (88) \\
\hline 33 & 11 & $2 \mathbf{b}(3)$ & 1.0 & aq $\mathrm{AcOH}$ & & 14b-Ac (53) \\
\hline 34 & 11 & $2 \mathrm{~g}(1.1)$ & 0.1 & $\mathrm{AcOH}$ & $\mathbf{1 4 g}(98)$ & \\
\hline
\end{tabular}

${ }^{a}$ The reaction was conducted at room temperature. ${ }^{b}$ The yield of the isolated aldo-benzimidazole product obtained by trituration of the reaction mixture with EtOAc. ${ }^{c}$ Overall yield of isolated product after peracetylation with $\mathrm{Ac}_{2} \mathrm{O}$ in pyridine. ${ }^{d}$ The reaction was conducted at $60{ }^{\circ} \mathrm{C}$ for $18 \mathrm{~h}$. ${ }^{e}$ Acetic acid buffer solution $(\mathrm{pH}=4.38)$.

laborious work in prior preparation of aldonic acids from the corresponding aldoses. ${ }^{6}$ For example, Moore and Link have previously applied this approach to synthesize two monosaccharide benzimidazoles, D-gluco- and D-galactobenzimidazoles, in 24 and $50 \%$ yields from D-glucose and D-galactose, respectively, by heating with cupric acetate ( 2 equiv) at $53{ }^{\circ} \mathrm{C}$ for $14 \mathrm{~h}$ in aqueous acetic acid solution (Scheme 1). ${ }^{5}$ Some saccharide bis-Schiff bases and quinoxalines also form as side products under such reaction conditions. ${ }^{3,5}$ However, using catalytic amounts of $\mathrm{CuSO}_{4}$ or replacing the $\mathrm{AcOH}$ solvent with aqueous $\mathrm{MeOH}$ does not give any desired aldo-benzimidazoles. ${ }^{5}$ Considering the acid-sensitive internal glycosidic bonds in disaccharides and higher saccharides, it is questionable that the corresponding aldo-benzimidazoles can be obtained by the above-mentioned reactions involving acidic conditions at high reaction temperature.

As a continuation of our study of the novel transformation of aldehydes and aldoses by use of amines and iodine, ${ }^{7}$ we describe herein an improved protocol for the synthesis of various aldo-benzimidazoles and aldo-naphthimidazoles by direct oxidative condensation of aldoses, including mono-, di-, and trisac-

(7) (a) Talukdar, S ; Hsu, J-L ; Chou, T-C ; Fang, J-M Tetrahedron Lett 2001, 42, 1103-1105. (b) Chen, M.-Y.; Hsu, J.-L.; Shie, J.-J.; Fang, J.-M. J. Chin. Chem. Soc. 2003, 50, 129-133. (c) Shie, J.-J.; Fang, J.-M. J. Org. Chem. 2003, 68, 1158-1160. (d) Shie, J.-J.; Fang, J.-M. J. Org. Chem. 2007, 72, 3141 3144 . charides, with $o$-phenylenediamines and 2,3-naphthalenediamine in the presence of iodine. We also demonstrate that the composition analysis of carbohydrate molecules is facilitated by incorporating the naphthimidazole moiety as a fluorescent label for sensitive detection.

\section{Results and Discussion}

Molecular iodine is a convenient and environmental benign oxidizing agent in organic synthesis. ${ }^{8}$ Two recent studies show that aliphatic and aromatic aldehydes react with 1,2-diamines to give the corresponding imidazolines in the presence of stoichiometric amounts of iodine. ${ }^{9}$ The reactions are conducted at high temperature $\left(70-90{ }^{\circ} \mathrm{C}\right)$ in protic solvents $\left(\mathrm{H}_{2} \mathrm{O}\right.$ or $t$ - $\mathrm{BuOH}$ ) using $\mathrm{K}_{2} \mathrm{CO}_{3}$ as the base to neutralize the generated hydroiodic acid. In one study, ${ }^{9 a} \mathrm{KI}$ is also used as a promoter in the reaction. So far, these methods have not been applied to aldoses, presumably because the hydroxyl groups in aldoses may also be oxidized by $\mathrm{I}_{2} / \mathrm{K}_{2} \mathrm{CO}_{3}$ at high temperature. ${ }^{7 \mathrm{~d}, 10}$

At the outset of our study, we tested the direct oxidative condensation of D-glucose (1a) with $o$-phenylenediamine (2a)

(8) Togo, H.; Iida, S. Synlett 2006, 14, 2159-2175, and references cited therein.

(9) (a) Gogoi, P.; Konwar, D. Tetrahedron Lett. 2006, 47, 79-82. (b) Ishihara, M.; Togo, H. Synlett 2006, 227-230.

(10) Mori, N.; Togo, H. Tetrahedron 2005, 61, 5915-5925. 


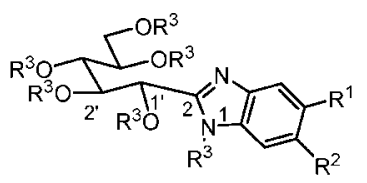

from D-Glucose

\begin{tabular}{llll} 
& $\mathrm{R}^{1}$ & $\mathrm{R}^{2}$ & $\mathrm{R}^{3}$ \\
\cline { 2 - 4 } 3a & $\mathrm{H}$ & $\mathrm{H}$ & $\mathrm{H}$ \\
3a-Ac & $\mathrm{H}$ & $\mathrm{H}$ & $\mathrm{Ac}$ \\
3b-Ac & $\mathrm{Me}$ & $\mathrm{Me}$ & $\mathrm{Ac}$ \\
3c & $\mathrm{Cl}$ & $\mathrm{Cl}$ & $\mathrm{H}$ \\
3d & $\mathrm{Me}$ & $\mathrm{H}$ & $\mathrm{H}$ \\
3e & $\mathrm{NO}_{2}$ & $\mathrm{H}$ & $\mathrm{H}$ \\
3f & $\mathrm{PhC}=\mathrm{O}$ & $\mathrm{H}$ & $\mathrm{H}$
\end{tabular}

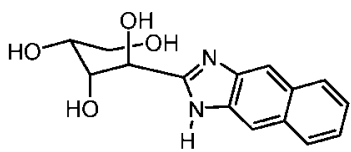

$6 \mathrm{~g}$ from D-Arabinose
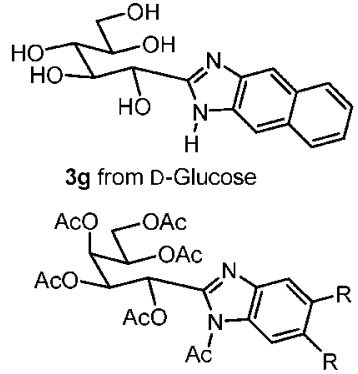

from $D-G a l a c t o s e$

4a-Ac $\quad \mathrm{R}=\mathrm{H}$

4b-Ac $\mathrm{R}=\mathrm{Me}$
$3 \mathrm{~g}$ from D-Glucose

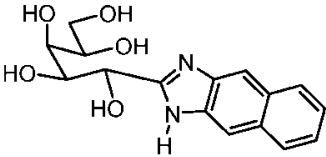

$4 \mathrm{~g}$ from D-Galactose

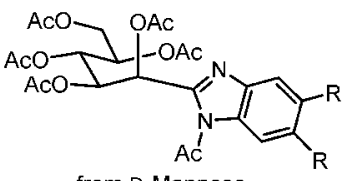

from $D-M a n n o s e$

5a-Ac $\quad \mathrm{R}=\mathrm{H}$

5b-Ac $\mathrm{R}=\mathrm{Me}$

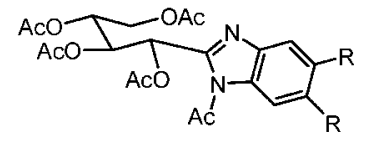

from $D-X y l o s e$

7a-Ac $\quad \mathrm{R}=\mathrm{H}$

7b-Ac $\mathrm{R}=\mathrm{Me}$

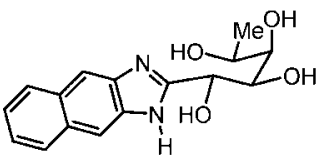

$9 \mathrm{~g}$ from L-Fucose

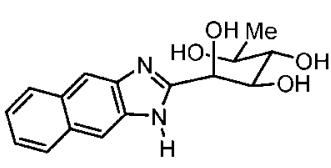

$10 \mathrm{~g}$ from L-Rhamnose

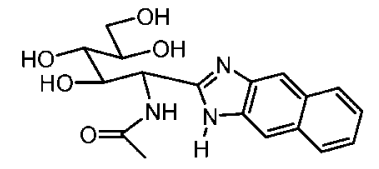

$11 \mathrm{~g}$ from D-GlcNAC

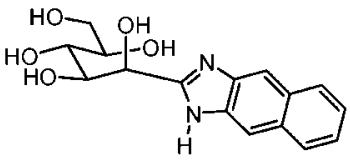

$\mathbf{5 g}$ from D-Mannose

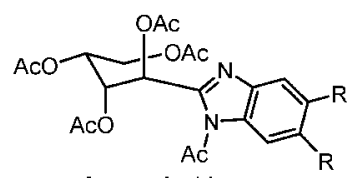

from $D$-Arabinose

6a-Ac $\mathrm{R}=\mathrm{H}$

6b-Ac $\mathrm{R}=\mathrm{Me}$

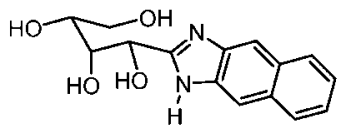

$8 g$ from D-Ribose

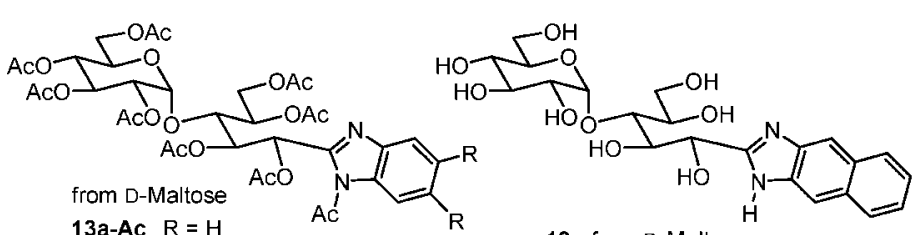

$13 \mathrm{~g}$ from D-Maltose

13a-Ac $\mathrm{R}=\mathrm{H}$

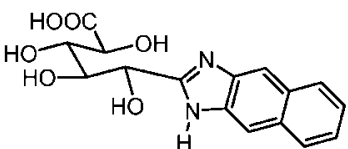

$12 \mathrm{~g}$ from D-GIcA

13b-Ac $R=M e$

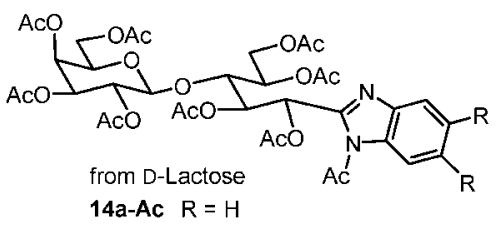

14b-Ac $R=M e$

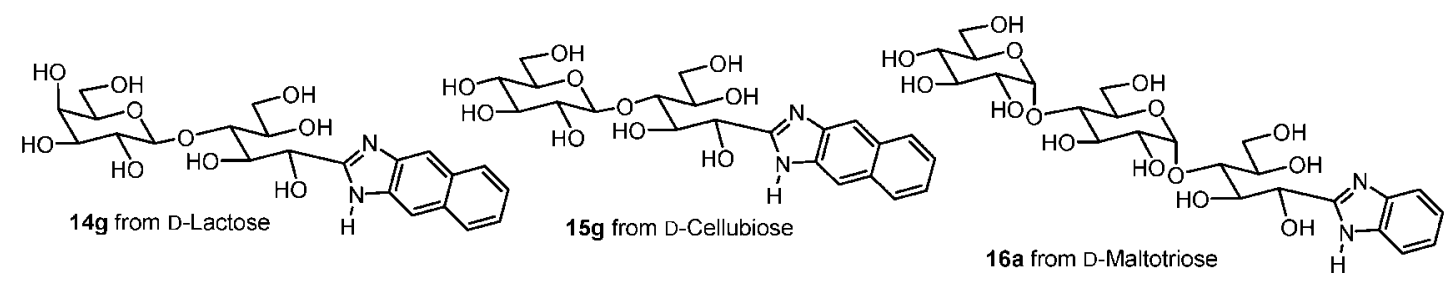

FIGURE 1. Structures of the products of aldo-benzimidazoles, aldo-naphthimidazoles, and their peracetylation compounds.

in the $\mathrm{I}_{2} / \mathrm{KI} / \mathrm{K}_{2} \mathrm{CO}_{3} / \mathrm{H}_{2} \mathrm{O}$ system $\left(90{ }^{\circ} \mathrm{C}, 1 \mathrm{~h}\right)$ similar to that reported by Gogoi and Konwar. ${ }^{9 a}$ However, this operation failed to give the desired aldo-benzimidazole product. We also surveyed the oxidative condensation reaction of D-glucose with $o$-phenylenediamine and iodine in various solvents, including $\mathrm{CHCl}_{3}, \mathrm{THF}, \mathrm{Me}_{2} \mathrm{CO}, \mathrm{CH}_{3} \mathrm{CN}$, DMF, DMSO, $\mathrm{MeOH}, \mathrm{H}_{2} \mathrm{O}$, and concentrated $\mathrm{HCl}$ solution. None of them are suitable media for the anticipated reaction. After many attempts, we found that aqueous $\mathrm{AcOH}$ solution was the solvent of choice, and the oxidative condensation of saccharides with $o$-phenylenediamines (or 2,3-napthalenediamine) occurred readily at room temperature without using additives of $\mathrm{KI}$ or $\mathrm{K}_{2} \mathrm{CO}_{3}$. Thus, D-glucose was treated with $o$-phenylenediamine ( 1.1 equiv) and iodine (0.1 equiv) in acetic acid at room temperature for $8 \mathrm{~h}$ to give D-glucobenzimidazole (3a) in 98\% yield (entry 1, Table 1). The reaction was monitored by TLC analysis, and complete conversion of glucose to glucobenzimidazole was supported by the ${ }^{13} \mathrm{C}$ NMR spectrum of the reaction mixture. The crude product mixture was then triturated with EtOAc to give a practically pure D-glucobenzimidazole as a solid in nearly quantitative yield.
The sample could be purified by flash column chromatography for further analysis. The ${ }^{13} \mathrm{C}$ NMR spectrum of $\mathbf{3 a}$ in DMSO$d_{6}$ solution showed a signal at $\delta 156.2$ attributable to the C-2 of the newly formed benzimidazole ring (referring to the numbering in Figure 1). In the ${ }^{1} \mathrm{H}$ NMR spectrum (DMSO- $d_{6}$ ), the phenyl protons in benzimidazole appeared at lower fields $(\delta 7.71$ and 7.48$)$ than those in $o$-phenylenediamine. The proton at the $\mathrm{C}-1^{\prime}$ position of $\mathbf{3 a}$ occurred at $\delta 5.16$ as a doublet with a small coupling constant $(5.2 \mathrm{~Hz})$. The benzimidazole 3a was treated with $\mathrm{Ac}_{2} \mathrm{O}$ in pyridine to give the peracetylation derivative 3a-Ac, which was fully characterized by its physical and spectroscopic properties.

The similar reaction of D-glucose with 4,5-dimethyl-1,2benzenediamine (2b) and iodine (1 equiv) in aqueous $\mathrm{AcOH}$ solution, followed by acetylation in $\mathrm{Ac}_{2} \mathrm{O}$ /pyridine, gave the peracetylation compound $\mathbf{3 b}$-Ac in 58\% overall yield. The iodine-promoted oxidative condensation reactions of D-glucose with 4,5-dichloro-1,2-benzenediamine (2c) and 4-methyl-1,2benzenediamine (2d) were also effectively carried out at room temperature to afford the aldo-benzimidazoles $\mathbf{3 c}$ and $\mathbf{3 d}$, 
SCHEME 2. Oxidative Condensation of D-Glucose with $o$-Phenylenediamine Using $\mathbf{I}_{2}$ as the Oxidizing Agent.

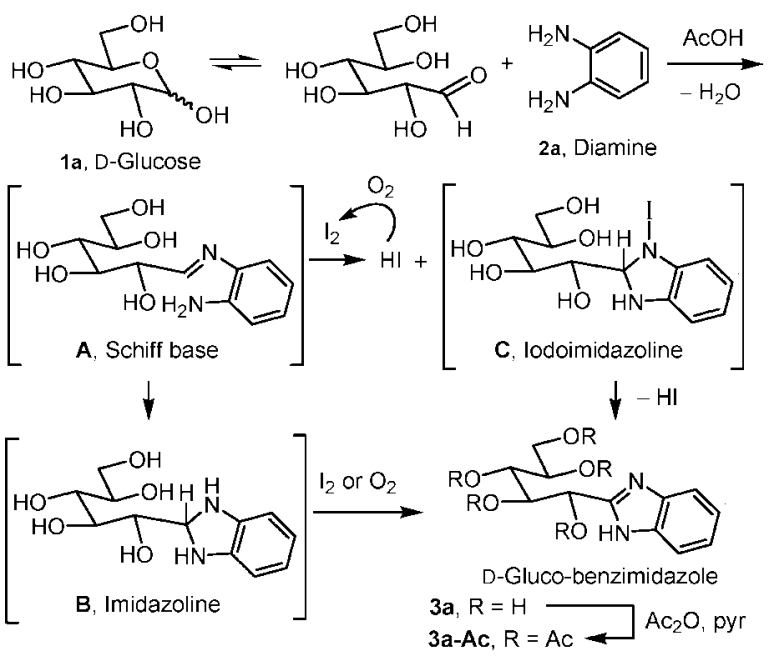

whereas the reactions with 4-nitro-1,2-benzenediamine (2e) and 4-benzoyl-1,2-benzenediamine (2f) were conducted at an elevated temperature $\left(60{ }^{\circ} \mathrm{C}\right)$. It appeared that the oxidative condensation reactions were accelerated by the electron-donating substituents and decelerated by the electron-withdrawing groups on the phenyl ring of $o$-phenylenediamine.

The oxidative condensation of glucose with 2,3-naphthalenediamine using $\mathrm{I}_{2}$ ( 0.1 equiv) as the promoter gave $98 \%$ yield of the desired aldo-naphthimidazole $\mathbf{3 g}$ (entry 7 , Table 1). However, the yield of $\mathbf{3 g}$ greatly deteriorated to $33 \%$ in the absence of $I_{2}$ (entry 8 ).

On the basis of the experimental results, we speculated that the reaction was initiated by formation of a Schiff base (e.g., the intermediate $\mathbf{A}$ in Scheme 2) by condensation of the aldose with one of the amino groups in $o$-phenylenediamine $(\mathbf{2 a}-\mathbf{f})$ or naphthalenediamine $\mathbf{2 g}$. The condensation of an aldehyde with an amine to form the Schiff base is a reversible process, in which formation of the Schiff base is favored under mild acidic conditions (e.g., at $\mathrm{pH} 4-6$ ). This rationale may support our finding that acetic acid is an appropriate solvent for the transformation of glucose to aldo-imidazoles. The subsequent nucleophilic addition of the other amino group to Schiff base A would give an imidazoline intermediate $\mathbf{B}$, which could be oxidized in air or by iodine to afford the observed product of aldo-benzimidazole. In deed, a previous report ${ }^{11}$ has shown that aromatic aldehydes are converted to the corresponding benzimidazoles by heating with $o$-phenylenediamines at $100^{\circ} \mathrm{C}$ in dioxane solution using air as the oxidant. The aldo-imidazole products might also form via a different pathway. ${ }^{12} \mathrm{~A}$ prior $\mathrm{N}$-iodination of the imine moiety in Schiff base A would facilitate the formation of iodoimidazoline intermediate $\mathbf{C}$, and the desired product of aldo-benzimidazole would be obtained by the subsequent elimination of an HI molecule. It was noted that another HI molecule was also generated during $\mathrm{N}$-iodination of the Schiff base. In the HOAc media, the released $\mathrm{I}^{-}$ions might be oxidized in air to regenerate $\mathrm{I}_{2}$. Our model experiment showed that colorless KI salt in acetic acid solution was gradually turned into a yellow solution of iodine by stirring in air at room temperature. This rationale may explain the

(11) Lin, S.; Yang, L. Tetrahedron Lett. 2005, 46, 4315-4319.

(12) Maggio-Hall, L. A.; Dorrestein, P. C.; Escalante-Semerena, J. C.; Begley, T. P. Org. Lett. 2003, 5, 2211-2213.

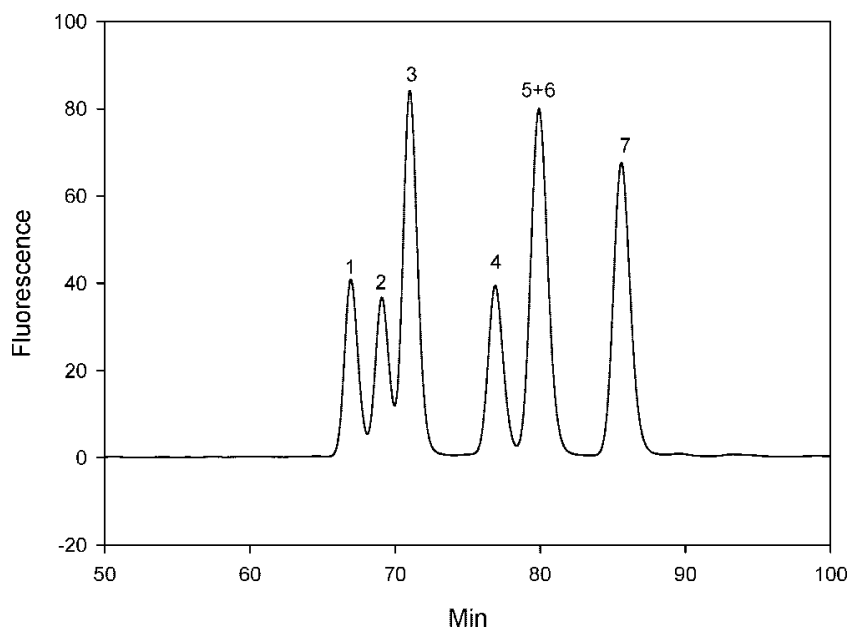

FIGURE 2. HPLC chromatograph of pentose and hexose naphthimidazoles on a pair of $\mathrm{HC}-\mathrm{C}_{18}$ column $(250 \mathrm{~mm} \times 4.6 \mathrm{~mm} ; 5 \mu \mathrm{m}$ porosity $)$ at $30{ }^{\circ} \mathrm{C}$. The mobile phase is sodium phosphate buffer $(100 \mathrm{mM}, \mathrm{pH}$ 5.0) containing $28 \%$ methanol and $2 \%$ acetonitrile at a flow rate of 0.8 $\mathrm{mL} / \mathrm{min}$. The fluorescence detection wavelength is $326 \mathrm{~nm}$, and the excitation wavelength is $232 \mathrm{~nm}$. The sample is a mixture of aldonaphthimidazoles, including those derived from D-mannose $(\mathbf{5 g}$, peak 1), D-glucose (3g, peak 2), D-galactose (4g, peak 3), D-ribose (8g, peak 4), D-arabinose/D-xylose $(6 \mathbf{g} / 7 \mathbf{g}$, peak $5+6)$, and L-fucose $(\mathbf{9 g}$, peak 7) at a concentration of $10 \mathrm{ppm}$ for each component.

quantitative yield of the aldo-imidazole product that was obtained even with only $10 \mathrm{~mol} \%$ of iodine as the oxidation promoter.

By using $\mathrm{I}_{2}$ as the oxidant/promoter in $\mathrm{AcOH}$ solution, various mono-, di-, and trisaccharides $(\mathbf{1} \mathbf{b}-\mathbf{n})$ also reacted with diamines $\mathbf{2} \mathbf{a}-\mathbf{g}$ to give the corresponding oxidative condensation products (entries 9-36 in Table 1). No racemization at the stereogenic centers or cleavage of the glycoside bonds was observed under such mild reaction conditions. $N$-Acetylglucosamine (1i) and glucuronic acid (1j) were also smoothly converted to the corresponding naphthimidazoles $\mathbf{1 1 g}$ and $\mathbf{1 2 g}$ in $94 \%$ and $97 \%$ yields, respectively (entries 27 and 28), indicating that the acetamido and carboxyl groups were inert in such reaction conditions. The structure of aldo-benzimidazole 16a derived from D-maltotriose was rigorously determined by NMR analyses including the two-dimensional HSQC spectrum. Our current method for a direct conversion of trisaccharide to the corresponding imidazole product is unique and likely applicable to the oxidative condensation of oligo- and polysaccharides with various aromatic vicinal diamines. This reaction protocol is particularly useful when the prior preparation and isolation of oligosaccharide acid or $\delta$-lactone are problematic.

Carbohydrates play essential roles in living organisms. However, carbohydrate molecules are not easily tracked due to lack of a responsive chromophore. Thus, properly labeled saccharides are desirable for their composition analysis. Though fluorescent labels can be introduced to aldoses by reductive amination, ${ }^{13}$ this method still has limitations such as low reactivity and low yield on modification of oligosaccharides. Our current method using the iodine-promoted oxidative condensation reactions provides an alternative way to convert aldoses to highly fluorescent aldo-naphthimidazoles in a direct

(13) (a) Baues, R. J.; Gray, G. R. J. Biol. Chem. 1977, 252, 57-60. (b) Anumula, K. R. Anal. Biochem. 2006, 350, 1-23. (c) Larsen, K.; Thygesen, M. B.; Guillaumie, F.; Willats, W. T.; Jensen, K. J. Carbohydr. Res. 2006, 341, 1209-1234. 
and efficient manner. Our preliminary study indicated that several aldo-naphthimidazoles derived from pentoses and hexoses were resolved by HPLC on reversed-phase columns (Figure 2 ). The detection limit was around $1 \mathrm{ppm}$. The analysis of aldonaphthimidazoles can be further investigated by using capillary electrophoresis as a high-resolution and sensitive method.

\section{Conclusion}

Using iodine as an oxidant/promoter, various aldoses react readily with $o$-phenylenediamines or 2,3-naphthalenediamine in acetic acid solution to form the corresponding aldo-benzimidazoles and aldo-naphthimidazoles in high yields. Other functional groups such as hydroxyl, carboxyl, and amido groups are inert in the mild reaction conditions. Thus, the oxidative condensation reactions of various aldoses were realized without protection or modification of other functional groups. The success of this method relies on the crucial role of iodine and choice of acetic acid as the solvent. This protocol shows advantages over the previous methods ${ }^{3,5}$ by conducting the oxidative condensation reactions under mild conditions in a onepot procedure to give high yields of aldo-imidazole products, which can be isolated simply by trituration of the crude reaction mixture with ethyl acetate. No racemization of saccharides or cleavage of the glycoside bonds occurs in our reaction protocol. In contrast to the starting materials of fluorescence-insensitive aldose and 2,3-naphthalenediamine, the aldo-naphthimidazole is highly fluorescent. Such property of enhanced fluorescence is potentially useful to the research of glycochemistry and glycobiology. In a preliminary study, we have demonstrated an application in carbohydrate composition analysis via the aldonaphthimidazole derivatives.

\section{Experimental Section}

General Procedure for Oxidative Condensation of Aldoses with o-Phenylenediamines or 2,3-Naphthalenediamine. Method A. An appropriate aldose $(1.0 \mathrm{mmol})$ and $o$-phenylenediamine $(192 \mathrm{mg}$, $3.0 \mathrm{mmol})$ were dissolved in a solution containing acetic acid (1 $\mathrm{mL}$ ) and water $(7 \mathrm{~mL})$. The mixture was stirred with a solution of iodine $(254 \mathrm{mg}, 1.0 \mathrm{mmol})$ in $\mathrm{MeOH}(2 \mathrm{~mL})$ at room temperature until the aldose was completely consumed as indicated by the TLC analysis. During the reaction period, the deep brown color of reaction mixture remained. The reaction was quenched by addition of $\mathrm{Na}_{2} \mathrm{~S}_{2} \mathrm{O}_{3}$ ( $2 \mathrm{~mL}$ of saturated aqueous solution), and the mixture was concentrated under reduced pressure to give the crude products of aldo-benzimidazoles.

The crude aldo-benzimidazole product was treated with acetic anhydride $(2 \mathrm{~mL})$ and pyridine $(2 \mathrm{~mL})$ at $0-25{ }^{\circ} \mathrm{C}$ for $8 \mathrm{~h}$ and then partitioned between $1 \mathrm{~N} \mathrm{HCl}(30 \mathrm{~mL})$ and $\mathrm{CH}_{2} \mathrm{Cl}_{2}(50 \mathrm{~mL})$. The organic phase was washed once with brine $(30 \mathrm{~mL})$, concentrated under reduced pressure, and purified by silica gel column chromatography (EtOAc/hexane, 1:2) to afford the desired product of aldo-benzimidazole peracetatate.

Method B. The oxidative condensation reactions were also performed in buffer solution. Thus, an appropriate aldose (1.0 $\mathrm{mmol})$ and $o$-phenylenediamine $(2.0 \mathrm{mmol}, 132 \mathrm{mg})$ was dissolved in acetic acid buffer solution ( $4 \mathrm{~mL}, \mathrm{pH} 4.38$ ). Iodine (1.0 mmol, $254 \mathrm{mg}$ dissolved in $2 \mathrm{~mL}$ of methanol) was added, and the mixture was stirred at room temperature until the aldose was completely consumed as indication of the TLC analysis. The reaction mixture was quenched by $\mathrm{Na}_{2} \mathrm{~S}_{2} \mathrm{O}_{3}$, concentrated, and subjected to peracetylation with $\mathrm{Ac}_{2} \mathrm{O} /$ pyridine to afford the desired product of aldobenzimidazole peracetatate.

Method C. A mixture of aldose $(0.02 \mathrm{mmol}), 2,3$-naphthalenediamine $(3.5 \mathrm{mg}, 0.022 \mathrm{mmol})$, and iodine $(0.5 \mathrm{mg}, 0.002 \mathrm{mmol})$ in $\mathrm{AcOH}(5.0 \mathrm{~mL})$ was stirred at room temperature in open air. The reaction was complete in $6 \mathrm{~h}$ as indicated by the TLC analysis. The reaction mixture was triturated with EtOAc to give precipitates, which were collected by filtration using nylon membrane filter. The aldo-naphthimidazole products prepared as such was practically pure for characterization. This protocol is applicable to the reaction of larger scale, e.g., 2 mmol.

HPLC Analysis of Aldo-naphthimidazoles. For UV detection, the detection wavelength is set at $310 \mathrm{~nm}$. For fluorescence detection, the excitation wavelength is $232 \mathrm{~nm}$ and the detection wavelength is $326 \mathrm{~nm}$. The sample was eluted on a pair of $\mathrm{HC}-\mathrm{C}_{18}$ column $(250 \mathrm{~mm} \times 4.6 \mathrm{~mm} ; 5 \mu \mathrm{m}$ porosity $)$ at $30{ }^{\circ} \mathrm{C}$, and the retention time of sample components was recorded. The mobile phase is sodium phosphate buffer $(100 \mathrm{mM}, \mathrm{pH} 5.0)$ containing $28 \%$ methanol and $2 \%$ acetonitrile at a flow rate of $0.8 \mathrm{~mL} / \mathrm{min}$.

(1'S,2'R,3'R,4'R)-1-Acetyl-5,6-dimethyl-2-(1,2,3,4,5-pentaacetoxy)pentylbenzimidazole (3b-Ac). According to the general procedure (method A), D-glucose $(180 \mathrm{mg}, 1.0 \mathrm{mmol})$ and 4,5-dimethyl-1,2benzenediamine $(396 \mathrm{mg}, 3.0 \mathrm{mmol}$ ) were stirred with iodine in aqueous $\mathrm{AcOH}$ solution for $11 \mathrm{~h}$ at room temperature. The crude product was subsequently treated with $\mathrm{Ac}_{2} \mathrm{O}$ in pyridine to give compound 3b-Ac (319 mg, 58\% overall yield). $\mathrm{C}_{26} \mathrm{H}_{32} \mathrm{~N}_{2} \mathrm{O}_{11}$ : yellowish solid, $\mathrm{mp}=83-85^{\circ} \mathrm{C}$; TLC (EtOAc/hexane, 1:2) $R_{f}=$ $0.16 ;[\alpha]^{25}{ }_{\mathrm{D}}+63.1\left(c 1.2, \mathrm{CHCl}_{3}\right) ; \mathrm{IR} v_{\max }(\mathrm{NaCl}) 3456,1752,1367$, $1222,1036 \mathrm{~cm}^{-1} ;{ }^{1} \mathrm{H} \mathrm{NMR}\left(\mathrm{CDCl}_{3}, 400 \mathrm{MHz}\right) \delta 7.50(1 \mathrm{H}, \mathrm{s})$, $7.33(1 \mathrm{H}, \mathrm{s}), 6.60(1 \mathrm{H}, \mathrm{d}, J=3.6 \mathrm{~Hz}), 5.90(1 \mathrm{H}, \mathrm{dd}, J=5.6,3.6$ $\mathrm{Hz}), 5.55(1 \mathrm{H}, \mathrm{t}, J=5.6 \mathrm{~Hz}), 5.56-5.54(1 \mathrm{H}, \mathrm{m}), 4.38(1 \mathrm{H}, \mathrm{dd}$, $J=12.4,2.4 \mathrm{~Hz}), 4.26(1 \mathrm{H}, \mathrm{dd}, J=12.4,5.6 \mathrm{~Hz}), 2.82(3 \mathrm{H}, \mathrm{s})$, $2.39(3 \mathrm{H}, \mathrm{s}), 2.34(3 \mathrm{H}, \mathrm{s}), 2.20(3 \mathrm{H}, \mathrm{s}), 2.10(3 \mathrm{H}, \mathrm{s}), 2.08(3 \mathrm{H}$, s), $2.05(3 \mathrm{H}, \mathrm{s}), 1.93(3 \mathrm{H}, \mathrm{s}) ;{ }^{13} \mathrm{C} \mathrm{NMR}\left(\mathrm{CDCl}_{3}, 100 \mathrm{MHz}\right) \delta$ $169.9,169.4,169.2(2 \times), 169.0,168.9,149.3,140.5,134.1,133.1$, 129.8, 120.8, 113.6, 69.4, 69.3, 69.2, 69.0, 61.6, 26.9, 21.2, 21.1 $(2 \times), 21.0(2 \times), 20.7,20.3$; HRMS (ESI) calcd for $\mathrm{C}_{26} \mathrm{H}_{33} \mathrm{~N}_{2} \mathrm{O}_{11}$ 549.2079, found $\mathrm{m} / \mathrm{z}$ 549.2061 [M $+\mathrm{H}]^{+}$.

$\left(1^{\prime} S, 2^{\prime} R, 3^{\prime} R, 4^{\prime} R\right)-2-(1,2,3,4,5-P e n t a h y d r o x y l) p e n t y l-1 H$-naphthimidazole (3g). According to the general procedure (method $\mathrm{C})$, D-glucose $(3.6 \mathrm{mg}, 0.02 \mathrm{mmol})$ and 2,3-naphthalenediamine $(3.5$ $\mathrm{mg}, 0.022 \mathrm{mmol})$ were stirred with iodine $(0.5 \mathrm{mg}, 0.002 \mathrm{mmol})$ in $5.0 \mathrm{~mL}$ of $\mathrm{AcOH}$ for $6 \mathrm{~h}$ at room temperature. The crude product was triturated with EtOAc to give compound $\mathbf{3 g}(6.2 \mathrm{mg}, 98 \%$ yield). $\mathrm{C}_{16} \mathrm{H}_{18} \mathrm{~N}_{2} \mathrm{O}_{5}$ : brownish solid, $\mathrm{mp}=175-177{ }^{\circ} \mathrm{C}$; ${ }^{1} \mathrm{H} \mathrm{NMR}$ (DMSO- $\left.d_{6}, 600 \mathrm{MHz}\right) \delta 8.06(2 \mathrm{H}, \mathrm{s}), 7.94(2 \mathrm{H}, \mathrm{d}, J=6.2,3.2$ $\mathrm{Hz}) 7.46(2 \mathrm{H}, \mathrm{d}, J=6.2,3.2 \mathrm{~Hz}), 5.12(1 \mathrm{H}, \mathrm{d}, J=5.3 \mathrm{~Hz}), 4.20$ $(1 \mathrm{H}, \mathrm{dd}, J=5.3,1.6 \mathrm{~Hz}), 3.59(1 \mathrm{H}, \mathrm{dd}, J=8.6,1.3 \mathrm{~Hz})$, $3.52-3.48(2 \mathrm{H}, \mathrm{m}), 3.35(1 \mathrm{H}, \mathrm{dt}, J=11.9,0.9 \mathrm{~Hz}) ;{ }^{13} \mathrm{C} \mathrm{NMR}$ $\left(\mathrm{DMSO}-d_{6}, 150 \mathrm{MHz}\right) \delta 161.1(2 \times), 139.5(2 \times), 129.8(2 \times), 127.9$ (2×), $123.5(2 \times), 110.9,72.2,71.6,71.4,70.4,63.7$; HRMS (ESI) calcd for $\mathrm{C}_{16} \mathrm{H}_{19} \mathrm{~N}_{2} \mathrm{O}_{5} 319.1294$, found $m / z$ 319.1285 [M $\left.+\mathrm{H}\right]^{+}$.

$\left(1^{\prime} S, 2^{\prime} R, 3^{\prime} R, 4^{\prime} R\right)$-1-Acetyl-2-[1,2,4,5-tetraacetoxy-3-O-(2,3,4,5-tetraacetoxy- $\beta$-D-galactopyranosyl)]pentylbenzimidazole (14a-Ac). According to the general procedure (method B), D-lactose monohydrate (180 mg, $0.5 \mathrm{mmol}$ ) and $o$-phenylenediamine (108 mg, $1.0 \mathrm{mmol})$ were stirred with iodine (127 mg, $0.5 \mathrm{mmol})$ in aqueous $\mathrm{AcOH}$ buffer solution for $58 \mathrm{~h}$ at room temperature. The crude product was subsequently treated with $\mathrm{Ac}_{2} \mathrm{O}$ in pyridine to give compound 14a-Ac (359 mg, 88\% overall yield) without further purification. $\mathrm{C}_{36} \mathrm{H}_{44} \mathrm{~N}_{2} \mathrm{O}_{19}$ : yellowish foam; TLC (EtOAc/hexane, 1:1) $R_{f}=0.12$; $[\alpha]^{25}+40.3$ ( c 2.7, $\mathrm{CHCl}_{3}$ ); IR $v_{\max }(\mathrm{NaCl}) 3443,1750,1371$, 1227, $1047 \mathrm{~cm}^{-1} ;{ }^{1} \mathrm{H} \mathrm{NMR}\left(\mathrm{CDCl}_{3}, 400 \mathrm{MHz}\right) \delta 7.74-7.72(1 \mathrm{H}$, m), 7.66-7.63 (1 H, m), 7.39-7.31 (2 H, m) 6.63 (1 H, dd, $J=$ 2.8, $0.8 \mathrm{~Hz}), 5.74(1 \mathrm{H}, \mathrm{m}), 5.34(1 \mathrm{H}, \mathrm{d}, J=3.6 \mathrm{~Hz}), 5.22-5.19$ $(1 \mathrm{H}, \mathrm{m}), 5.13(1 \mathrm{H}, \mathrm{dd}, J=10,8 \mathrm{~Hz}), 5.00(1 \mathrm{H}, \mathrm{m}), 4.63(1 \mathrm{H}$, m), $4.41(1 \mathrm{H}, \mathrm{t}, J=5.6 \mathrm{~Hz}), 4.21(1 \mathrm{H}, \mathrm{dd}, J=10.8,7.2 \mathrm{~Hz})$, 4.02-3.92 (2 H, m), $3.84(1 \mathrm{H}, \mathrm{t}, 6.8), 2.88(3 \mathrm{H}, \mathrm{s}), 2.27(3 \mathrm{H}, \mathrm{s})$, $2.14(3 \mathrm{H}, \mathrm{s}), 2.13(3 \mathrm{H}, \mathrm{s}), 2.09(3 \mathrm{H}, \mathrm{s}), 2.06(3 \mathrm{H}, \mathrm{s}), 2.00(3 \mathrm{H}$, s), $1.98(3 \mathrm{H}, \mathrm{s}), 1.93(3 \mathrm{H}, \mathrm{s}) ;{ }^{13} \mathrm{C} \mathrm{NMR}\left(\mathrm{CDCl}_{3}, 100 \mathrm{MHz}\right) \delta$ 169.9, 169.8, $169.7(2 \times), 169.6(2 \times), 169.3,169.2,168.8,151.1$, $142.1,131.7,125.0,124.2,120.5,113.4,100.9,70.7,70.6,70.3$, $69.4,69.3,68.8,66.6,61.3,60.7,60.1,26.5,20.8,20.7,20.6(2 \times)$, 
$20.4(2 \times), 20.3,20.2$; HRMS (ESI) calcd for $\mathrm{C}_{36} \mathrm{H}_{45} \mathrm{~N}_{2} \mathrm{O}_{19}$ 809.2613, found $\mathrm{m} / \mathrm{z} 809.2611[\mathrm{M}+\mathrm{H}]^{+}$.

Compound 16a Derived from Maltotriose. According to the general procedure (method C), D-maltotriose monohydrate (50.4 $\mathrm{mg}, 0.1 \mathrm{mmol})$ and $o$-phenylenediamine $(21.6 \mathrm{mg}, 0.2 \mathrm{mmol})$ were stirred with iodine $(25 \mathrm{mg}, 0.1 \mathrm{mmol})$ in $3.0 \mathrm{~mL}$ of $\mathrm{AcOH}$ for $30 \mathrm{~h}$ at room temperature. The crude product was purified by $\mathrm{C} 18$ reversed-phase silica gel column chromatography $\left(\mathrm{MeOH} / \mathrm{H}_{2} \mathrm{O}, 1 \%\right.$ to $30 \%$ as gradient) to afford the desired product $\mathbf{1 6 a}(30 \mathrm{mg}, 51 \%$ yield). $\mathrm{C}_{24} \mathrm{H}_{36} \mathrm{~N}_{2} \mathrm{O}_{15}$ : yellowish foam; TLC (acetone/EtOAc/ $\mathrm{H}_{2} \mathrm{O}$ / $\mathrm{AcOH}, 60: 30: 20: 1) R_{f}=0.44 ;[\alpha]{ }^{25} \mathrm{D}+55.40\left(c 1.0, \mathrm{H}_{2} \mathrm{O}\right) ;{ }^{1} \mathrm{H}$ NMR $\left(\mathrm{D}_{2} \mathrm{O}, 400 \mathrm{MHz}\right) \delta 7.62-7.60(2 \mathrm{H}, \mathrm{m}), 7.32-7.30(2 \mathrm{H}, \mathrm{m}), 5.37$ $(1 \mathrm{H}, \mathrm{d}, J=4.0 \mathrm{~Hz}), 5.21(1 \mathrm{H}, \mathrm{d}, J=4.4 \mathrm{~Hz}), 5.09(1 \mathrm{H}, \mathrm{d}, J=$ $3.6 \mathrm{~Hz}), 4.34-3.37(17 \mathrm{H}, \mathrm{m}){ }^{13} \mathrm{C} \mathrm{NMR}\left(\mathrm{CD}_{3} \mathrm{OD}, 150 \mathrm{MHz}\right) \delta$
154.9, $121.2(4 \times), 115.3(2 \times), 100.7,100.2,81.2,77.4,73.8,73.6$, $73.3,73.0,72.2,71.9,71.6,71.3,69.7,69.0,62.6,60.8,60.4$; the assignments of proton and carbon resonances were supported by the HSQC spectrum; HRMS (ESI) calcd for $\mathrm{C}_{24} \mathrm{H}_{37} \mathrm{~N}_{2} \mathrm{O}_{15} 593.2188$, found $\mathrm{m} / \mathrm{z} 593.2190[\mathrm{M}+\mathrm{H}]^{+}$.

Acknowledgment. We thank the National Science Council for financial support.

Supporting Information Available: Synthetic procedures, physical and spectroscopic data of products; ${ }^{1} \mathrm{H}$ and ${ }^{13} \mathrm{C}$ NMR spectra. This material is available free of charge via the Internet at http://pubs.acs.org.

JO800234X 